\title{
When horsetails became giants
}

\author{
FENG Zhuo $^{1,2^{*}}$, ZIEROLD Thorid $^{1} \&$ RÖßLER Ronny ${ }^{1 *}$ \\ ${ }^{1}$ Museum für Naturkunde, Chemnitz, Moritzstraße 20, 09111, Germany; \\ ${ }^{2}$ Yunnan Key Laboratory for Palaeobiology, Yunnan University, Kunming 650091, China
}

Received January 12, 2012; accepted February 17, 2012; published online April 12, 2012

\begin{abstract}
Horsetails arose in the Late Devonian, evolved a greater diversity and forming fast growing bamboo-like thickets in the Carboniferous lowland swamp forest ecosystems. However, the diversity of this group drastically declined during the Permian while the climate became more dynamic and arid. Today only a single surviving genus exists, the herbaceous Equisetum. Here we report an exceptional large horsetail tree from the Early Permian Petrified Forest of Chemnitz. This fossil horsetail tree is assigned to Arthropitys bistriata (Cotta) Goeppert. It is $15 \mathrm{~m}$ high and over $25 \mathrm{~cm}$ in diameter, with thick wood and at least 3 orders of woody branching system formed a big canopy, and is morphologically very comparable with the living woody higher plants. This suggests that the plasticity mechanism of Permian calamitaleans enabled novel growth strategies when they competed with the rising gymnosperms during the environmental changes.
\end{abstract}

horsetail, Arthropitys bistriata, Early Permian, Chemnitz Petrified Forest, Germany

Citation: $\quad$ Feng Z, Zierold T, Rößler R. When horsetails became giants. Chin Sci Bull, 2012, 57: 2285-2288, doi: 10.1007/s11434-012-5086-2

Horsetail ancestors, which arose in the Late Devonian [1], evolved a greater diversity in the Carboniferous when these plants inhabited the lowland equatorial swamp forest ecosystems [2], forming fast growing bamboo-like thickets of up to $20 \mathrm{~m}$ high $[3,4]$. A relict of these former woody horsetail trees is the free sporing herbaceous modern horsetail, the genus Equisetum known to consist of about 15 species $[5,6]$. Although the diversity of this plant group drastically declined during the Permian, a few forms exhibited unexpected adaptations [7] and persisted in some regions close to the Permian-Triassic mass extinction event [8]. However, the drier climate and more dynamic Permian environment resulted in a new competitive challenge for these plants to grow optimally and survive in competing with the rapid radiation of seed plants [9].

The Palaeozoic horsetail trees, known as calamites, are among the most common and frequently found plant fossils in Upper Carboniferous and Lower Permian rocks $[1,2]$. Most of the specimens so far found are fragmentary with only a portion of the plant body preserved. These plants are

\footnotetext{
*Corresponding authors (email: zhuofeng@ynu.edu.cn;
}

roessler@naturkunde-chemnitz.de) best understood from casts of their hollow stems and from coalified compressions of their leafy shoots and strobili. However, when compared to the overwhelming large number of casts and impressions/compressions, sizeable trunks that show anatomical preservation of the plant's cellular detail remain rather rare in the stratigraphic fossil record [7].

Here we describe an exceptional large horsetail fossil from the Petrified Forest of Chemnitz, Germany, which provides insights into both the spatial arrangement of the complex branching system and its anatomical details. The Permian horsetail tree shows a complex architecture consisting of multi-forked woody branches, which very different from the Carboniferous members. Therefore, we suggest that the evolved architecture plasticity enabled these plants to successfully compete with the rising gymnosperms and account for their persistence in single habitats.

\section{Material and methods}

The multi-branched horsetail tree Arthropitys bistriata (Cotta) Goeppert [7] was discovered in 2008 and finally 
excavated in 2011, from the Early Permian Petrified Forest of Chemnitz, Germany (5051'58.68"N, 1257'32.54"E). In this region, a subtropical forest ecosystem was buried in situ in a very short time by volcanic eruption. Thus preserving the autochthonous and parautochthonous assemblages of a fossil lagerstaette. During 2008 to 2011, we applied a systematic and well-documented excavation on this fossil lagerstaette in a site of nearly $24 \times 18 \mathrm{~m}^{2}$. The unearthed fossil specimens from this excavation site include 53 upright standing tree trunks, numerous transported stems and leaf impressions, as well as some fossil animals. Systematically, the fossil leaf assemblage mainly including Annularia spicata, Sphenophyllum sp., Lobatopteris geinitzii, Noeggerathia zamitoides, Alethopteris schneideri, Neurocallipteris planchardii, Taeniopteris abnormis, Walchia piniformis and several pecopterids and pteridosperm fructifications. The stratigraphic position of this fossil Lagerstaette corresponds to the Upper Asselian/Lower Sakmarian boundary [7].

In order to investigate the morphological and internal structure of the fossil horsetail tree in detail, we used a sand blaster to clear the surface of the stem and branches. The specimen was subsequently cut with a trimming saw to reveal both transverse and longitudinal (radial and tangential) sections. These section surfaces were ground and polished, and examined using reflected light microscopy. Sections were examined and photographed under reflected light using Nikon Eclipse ME 600 and Nikon SMZ 1500 microscopes both equipped with a Nikon DS-5M-L1 digital cam- era. The hand specimen photographs were taken by using a Nikon D300 with AF-S Micro Nikkor 105 mm 1:2.8G lens. Composite images were created using Adobe Photoshop CS v. 8.0, and corrected only for contrast. The specimen and thin slices are housed in the Museum für Naturkunde Chemnitz, labelled KH0052, KH0054, KH0057, KH0058 and $\mathrm{KH} 0072$.

\section{Results}

The well preserved specimen, Arthropitys bistriata, is unusual, because it is estimated to have been more than $15 \mathrm{~m}$ in height with at least 3 orders of secondary woody branches (Figures 1(a) and 2) forming a large canopy. This is the first time that the branching architecture of an anatomically preserved calamite tree clearly observed in three dimensions. The plant shows two types of branches: one branch type is leafy twigs covered by leaves and the other is adventitious shoots. The leafy twigs show no signs of any secondary growth and are arranged in whorls at particular nodes (Figure 1(e), arrows), both on the main stem and on adventitious shoots. The adventitious shoots are woody branches that originate inside the secondary xylem, rapidly enlarge by growth of secondary xylem, depart at angles of $25^{\circ}-35^{\circ}$ from the main stem and generate another set of secondary or tertiary adventitious shoots, forming the complex branching system (Figure 2). As reported to date, most of calamitaleans
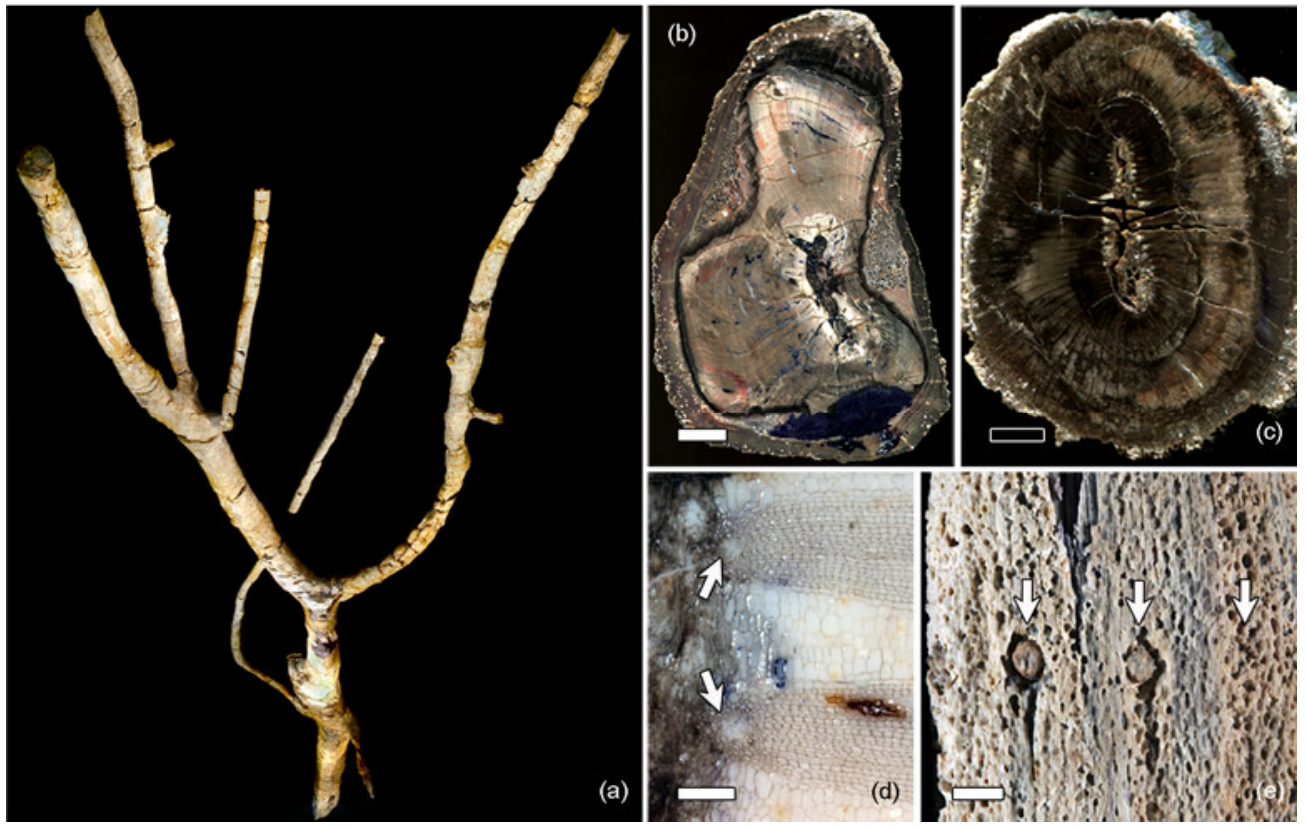

Figure 1 Multi-branched horsetail tree (Arthropitys bistriata) from the Early Permian Petrified Forest of Chemnitz, Germany (specimen is housed in the Museum für Naturkunde Chemnitz, labelled KH0052, KH0054, KH0057, KH0058 and KH0072). (a) Distal view of the specimen showing the spatial architecture of the branches. (b) Transverse section (TS), from the lower portion of the main stem, showing extensive wood and an elliptical pith. Scale bar $=2$ $\mathrm{cm}$. (c) TS of woody adventitious shoot, showing large pith surrounded by a thick woody cylinder. Scale bar $=5 \mathrm{~mm}$. (d) TS of main stem showing the initial of xylem wedges and inter-fasicular rays, note the carinal canals (arrows) are surrounded by a few layers of small metaxylem cells. Scale bar $=2$ mm. (e) Traces of leafy twigs (arrows) arranged in whorls on the adventitious shoots. Scale bar $=5 \mathrm{~mm}$. 


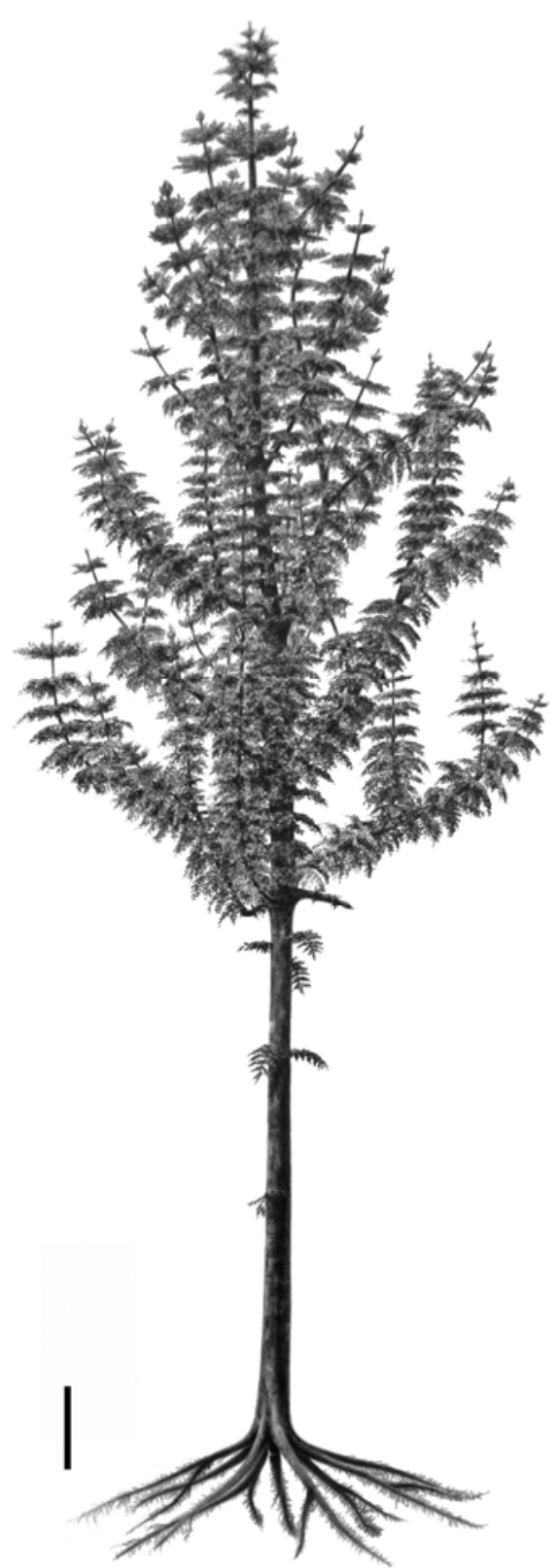

Figure 2 Proposed reconstruction of the horsetail tree (Arthropitys bistriata) from the Early Permian Petrified Forest of Chemnitz, Germany (drawing by Frederik Spindler. Scale bar $=1 \mathrm{~m}$ ).

are similar to extant horsetails, characterised by an extensive underground rhizome system from which upright aerial axes form in a clonal growth strategy [10]. However, unlike recent relatives, our Permian specimen possessed a densely developed woody trunk that grew to a diameter of at least $25 \mathrm{~cm}$ (Figure 1(b)). The wood cylinder that supported the tree consists of numerous fascicular wedges and interfascicular rays surrounding a large central pith cavity (Figure 1(c)). The carinal canal, from which the growth was initiated, is considered to be a conservative developmental character that indicates the position of the primary xylem both in living and fossil forms. In our Permian specimen, carinal canals usually are surrounded by small metaxylem cells (Figure 1(d), arrows).

\section{Discussion}

Arborescent equisetaleans were among the major constituents of the Carboniferous lowland equatorial swamp forest ecosystems [1]. The growing mode of the Carboniferous horsetail stem tends to parallel the epidogenic and apoxogenic development present in the arborescent lycopsids [3]. However, the high woody trunk with a multi-ordered branching system of a horsetail tree has never been documented before.

The growing mode of the multi-branched Chemnitz horsetail is very similar to that known in extant higher woody plants, when one compares the spatial organization of its adventitious shoots. Although plant architecture is believed to be determined by genetic developmental code [11], it is also influenced by environmental factors including light, temperature, humidity, nutrition, water table and density of vegetation. However, the development of branching patterns in extant woody plants is a complex physiological process that remains inadequately understood [12-14]. Previous studies show that living plants respond to local heterogeneity in both abiotic and biotic conditions by changing module-level morphology, growth, and reproductive patterns $[15,16]$.

Many Pennsylvanian ecosystems across Euramerica were situated in low-latitude humid environments largely consisting of tropical rainforests [17]. As the Euramerican climate increasingly became more seasonal and dry through the late Palaeozoic in response to tectonic activity, these rainforests collapsed, eventually being replaced by seasonally dry Permian biomes [18,19]. Although the causes of this aridification remain a matter of controversy, the consensus is that this climate shift led to the fragmentation of the coal-forming forests into isolated rainforest islands surrounded by xerophytic scrubs [9,20-23].

Large gymnospermous trunks, up to 30 meters in height, are common components of the Chemnitz Petrified Forest and represent the forest canopy in this landscape. Therefore, those elements growing in a lower storey, which received less sunlight than those in the upper storey, had to develop different strategies to receive the necessary amount of light needed for growth. The plants that occupied these habitats were forced into resource competition. As a result, horsetails established different ways to survive and even dominated in some places. Evidently, this plant group reached its evolutionary acme and evolved special adaptations in the earliest Permian. Both calamitaleans from Chemnitz and another important fossil locality in Tocantins, Brazil, show physiological modification, seasonally abscise leafy twigs in response to gradual environmental change in the Permian [24]. The presence of growth rings in woody Arthropitys 
trees (stem and roots) indicate that some kind of climatic periodicity was responsible for their development. Additionally Arthropitys is characterized by a wood composed of up to $50 \%$ parenchyma in the secondary xylem [7]. These features indicated that some, if not all, of the Permian calamitaleans may have survived short seasonal episodes of dryness during which time plants reduced water uptake and shed their leafy twigs. This inference is supported by the large-diameter, long living Arthropitys trunks [25]. Furthermore previous studies have shown that the rhizomes considered to promote a clonal habit in this plant are not functional in adolescent specimens, and completely disappeared in adults by producing a trunk base with woody adventitious roots anchoring the upright trees in the soil [24]. Compare with the shallow, horizontally arranged rhizomes, the anchoring like rooting system provides more surviving opportunities during the seasonally dry climate.

Many studies have shown the importance of resource uptake promoting architectural changes to plants growing under competitive conditions [26]. Neighbouring plants are an important factor that influences the availability of resources. Hence, the architectural mechanisms by which plants can alter their resource-gathering ability indicate their potential for success in different competitive situations [27]. Early Permian giant horsetail probably responded to local variability in resource availability with changes in their growth architecture to maximize a plant's resourcegathering ability in response to competition with other plants growing in the forest. These other plants include medullosan seed ferns, Psaronius tree ferns, and cordaitalean gymnosperms, all these taxa being frequently encountered from the same habitat at Chemnitz. However, this highly specialized functional feature of Arthropitys could not alter its eventual fate during the gradual increasing change in Permian climate and their final disappearance as part of the Permo-Triassic mass extinction.

We thank Ralph Kretzschmar, Volker Annacker, Robert Noll and Mathias Merbitz for the fieldwork, preparation and discussion; Robert A. Gastaldo for English presentation and Frederick Spindler for reconstruction drawing; two anonymous reviewers significantly improved this paper. This research was partially founded by the Volkswagen Foundation (Az.: I/84638), the National Natural Science Foundation of China (40902006 and 41172009) and the Specialized Research Fund for the Doctoral Program of Higher Education (20095301120003).

1 Taylor T N, Taylor E L, Krings M. Paleobotany: The Biology and Evolution of Fossil Plants. 2nd ed. Amsterdam: Elsevier Science and Technolology, 2009

2 DiMichele W A, Phillips T L. Paleobotanical and paleoecological constraints on models of peat formation in the Late Carboniferous of Euramerica. Palaeogeogr Palaeoclimatol Palaeoecol, 1994, 106: 39-90

3 Eggert D A. The ontogeny of Carboniferous arborescent Sphenopsida. Palaeontogr B, 1962, 110: 99-127
4 Jongmans W J. Anleitung zur Bestimmung der Karbonpflanzen West-Europas. I. Thallophytae, Equisetalses, Sphenophyllales, Staatl. Bohrverwaltung in den Niederlanden, Craz \& Gerlach, 1911

5 Hauke R L. A taxonomical monograph of the genus Equisetum subgenus Hippochaete. Nova Hedwigia Beih, 1963, 8: 1-123

6 Hauke R L. A taxonomic monograph of Equisetum subgenus Equisetum. Nova Hedwigia, 1978, 30: 385-455

7 Rößler R, Noll R. Anatomy and branching of Arthropitys bistriata (Cotta) Goeppert: New observations from the Permian petrified forest of Chemnitz, Germany. Int J Coal Geol, 2010, 83: 103-124

8 Wang S J, Hilton J, Galtier J, et al. A large anatomically preserved calamitean stem from the Upper Permian of southwest China and its implications for calamitean development and functional anatomy. Plant Sys Evol, 2006, 261: 229-244

9 Roscher M, Schneider J W. Permo-Carboniferous climate: Early Pennsylvanian to Late Permian climate development of central Europe in a regional and global context. In: Lucas S G, Schneider J W, eds. Non-marine Permian Biostratigraphy and Biochronology. London: Geological Society London, Special Publication, 2006. 95-136

10 Simpson M G. Plant Systematics. Amsterdam: Elsevier Academic Press, 2006

11 Wang Y, Li J. Genes controlling plant architecture. Ann Rev Plant Biol, 2008, 59: 253-279

12 Wilson B F. Apical control of branch growth and angle in woody plants. Am J Bot, 2000, 5: 601-607

13 Wang Y, Li J. Genes controlling plant architecture. Curr Opin Biotechnol, 2006, 17: 123-129

14 Yang Z, Midmore D J. Self-organisation at the whole-plant level: A modelling study. Funct Plant Biol, 2009, 36: 56-65

15 White J. The plant as a metapopulation. Ann Rev Ecol Syst, 1979, 10: 109-145

16 Kawamura K. A conceptual framework for the study of modular responses to local environmental heterogeneity within the plant crown and a review of related concepts. Ecol Res, 2010, 25: 733-744

17 DiMichele W A, Falcon-Lang H J, Elrick S D, et al. Ecological gradients within a Pennsylvanian forest. Geology, 2007, 35: 415-418

18 Kerp H. Post-Variscian late Palaeozoic Northern Hemisphere gymnosperms: The onset to the Mesozoic. Rev Palaeobot Palynol, 1996, 90: $263-285$

19 Montañez I P, Tabor N J, Niemeier D, et al. $\mathrm{CO}_{2}$-forced climate and vegetation instability during Late Paleozoic deglaciation. Science, 2007, 315: 87-91

20 Falcon-Lang H J. Pennsylvanian tropical rainforests responded to glacial-interglacial rhythms. Geology, 2004, 32: 689-692

21 Falcon-Lang H J, Nelson J, Elrick S, et al. Incised valley-fills containing conifers imply that seasonally-dry vegetation dominated Pennsylvanian lowlands. Geology, 2009, 37: 923-926

22 Falcon-Lang H J, DiMichele W A. What happened to the Coal Forests during glacial phases? Palaios, 2010, 25: 611-617

23 Sahney S, Benton M J, Falcon-Lang H J. Rainforest collapse triggered Carboniferous tetrapod diversification in Euramerica. Geology, 2010, 38: 1079-1082

24 Rößler R. Two remarkable Permian petrified forests: Correlation, comparison and significance. In: Lucas S G, Schneider J W, eds. Non-marine Permian Biostratigraphy and Biochronology. London: Geological Society London, Special Publication, 2006. 39-63

25 Rößler R, Noll R. Sphenopsids of the Permian (I): The largest known anatomically preserved calamite, an exceptional find from the petrified forest of Chemnitz Germany. Rev Palaeobot Palynol, 2006, 140: $145-162$

26 Grams T E E, Andersen C P. Competition for resources in trees: Physiological versus morphological plasticity. Prog Bot, 2007, 68: 356-381

27 Tremmel D C, Bazzaz F A. Plant architecture and allocation in different neighborhoods: Implications for competitive success. Ecology, 1995, 76: 262-271

Open Access This article is distributed under the terms of the Creative Commons Attribution License which permits any use, distribution, and reproduction in any medium, provided the original author(s) and source are credited. 